Jurnal Indonesia Sosial Teknologi:p-ISSN: 2723 - 6609

e-ISSN :2745-5254

Vol. 3, No.1 Januari 2022

\title{
MANAJEMEN RANTAI PASOKAN PERUSAHAAN PT.AGRO AKU BISA
}

\author{
Alvian Yusril Santoso', Rahmat Agus Santoso ${ }^{2}$ \\ Program Studi Manajemen Universitas Muhammadiyah Gresik ${ }^{1,2}$ \\ Email: vianyusril17@gmail.com ${ }^{1}$, ra.santoso@umg.ac.id²
}

\begin{abstract}
Abstrak
Jagung merupakan salah satu komoditas jagung yang sangat vital di kemudian hari. Jagung juga merupakan salah satu bahan pokok karena kekurangannya sebagai bahan pangan alami yang memiliki manfaat diet tinggi dan merupakan sumber utama gula dan protein. Penelitian ini dilakukan di PT. Agro Aku Bisa jember jawa timur, untuk memenuhi persyaratan memenuhi persyaratan kebutuhan dari konsumen serara efisien untuk mana yang akan datang, SCM dalam industri pertanian jagung mendapatkan informasi persediaan bibit, hasil tani, dan pendistribusian hasil pertanian jagung lebih optimal supaya SCM dalam industri pertanian jagung dapat berjalan optimal, efektif dan efisien. Tujuan penelitian ini Tujuan Penelitian ini adalah untuk mengetahui kinerja manajemen rantai pasokan perusahaan PT.Agro Aku Bisa, bagaimana cara mendistribusikan bahan baku ke petani,bagaimana proses produksi dan hasil panen. Penelitian ini tergolong pada jenis penelitian kualitiatif dengan menggunakan data primer yang meliputi wawancara dan observasi langsung. Agroindustri Pelaku Supply chain Adalah Agroindustri. Agroindustri yang dimaksud adalah agroindustri Perusahaan Jagung. Agroindustri perusahaan Jagung yang menjadi pelaku supply chain ini berada di JL. Kyai Mojo, Kaliwates, Jember, Jawa Timur. Pemasok Pemasok adalah pelaku Supply chain setelah Agroindustri. Pemasok yang dimaksud berasal dari beberapa perusahaan yang memproduksi pupuk, bibit tanaman, obaat-obatan untuk pertanian, Pemasok atau vendor yang bekerja sama dengan PT. Agro Aku Bisa Yakni PT. Petrosida Gresik. Rantai pasokan agroindustri PT. Agro Aku Bisa adalah perusahaan Agroindustri - PT. Agro aku bisa - petani - Pemask - produsen Konsumen
\end{abstract}

Kata kunci: Supply Chain Management; Operasional Perusahaan; Inventori; logistik.

\section{Abstract}

Corn (Zea mays) is one of the most imperative corn products later on. Corn is likewise one of the staples in light of its need as a characteristic food fixing that has high dietary advantages and is the primary wellspring of sugar and protein. This exploration was directed at PT. Agro Aku Bisa, Jember, East Java, to meet the necessities of meeting the prerequisites of shoppers in a proficient way for the future, SCM in the corn cultivating industry gets data on seed stock, agrarian produce, and appropriation of corn rural items all the more ideally so SCM in the corn cultivating industry can running ideally, viably and productively. The motivation behind this review The reason for this review was to decide the presentation of store network the executives organization PT.Agro Aku Bisa, how 
to convey unrefined components to ranchers, how the creation cycle and yields. This examination has a place with the kind of subjective exploration utilizing essential information which incorporates meets and direct perception. Agroindustry Production network entertainers are agroindustry. The agroindustry being referred to is the corn organization agroindustry. The corn organization agro-industry which is a production network entertainer is situated at JL. Kyai Magic, Kaliwates, Jember, East Java. Providers are production network entertainers after Agroindustry. The providers being referred to come from a few organizations that produce composts, sow seeds, drugs for farming, providers or merchants who cooperate with PT. Agro Aku Bisa Specifically PT. Petroside Gresik. Agro-industry store network PT. Agro Aku Bisa is an Agroindustry organization - PT. Agro Aku Bisa - rancher-maker-maker - shopper

Keywords: Supply Chain Management; Company Operation; Invemtory; Logistic.

\section{Pendahuluan}

Jagung (Zea mays) merupakan salah satu komoditas jagung yang sangat vital di kemudian hari (Adiputra, 2020). Jagung juga merupakan salah satu bahan pokok karena kekurangannya sebagai bahan pangan alami yang memiliki manfaat diet tinggi dan merupakan sumber utama gula dan protein. Jagung merupakan tanaman yang kaya akan manfaat mulai dari daun, produk organik, dan batangnya. Perluasan dalam pengelolaan jagung diharapkan dapat membangun nilai jual dan mendukung pengembangan agroindustri, dengan tujuan dapat menyerap kerja dengan tujuan akhir untuk meringankan bantuan pemerintah pada komoditas jagung dan peternak khususnya (Lailia, 2014). Jagung juga merupakan salah satu produk agraris utama setelah padi dan kedelai. Jagung merupakan salah satu bahan pokok yang dibutuhkan masyarakat budidaya unggas dan berbagai usaha pangan lainnya yang ditangani. Jagung juga merupakan varietas tak tertandingi yang memiliki sifat hasil tinggi, memiliki harapan hidup yang pendek, dan aman dari penyakit. Jagung merupakan tanaman tahunan atau tahunan yang Siklus hidupnya selesai dalam 80-150 hari. Jagung adalah tanaman pangan utama di planet ini yang penting bagi keberadaan manusia dan makhluk hidup. Selain gandum dan beras, jagung merupakan sumber utama pati di Amerika Tengah dan Selatan, jagung juga merupakan sumber makanan pilihan di AS sebagai sumber gula. Hal ini merupakan sumber pangan yang dapat menggantikan beras sebagai makanan pokok di Indonesia. Beberapa daerah di Indonesia, misalnya Madura dan Nusa Tenggara, menggunakan jagung sebagai makanan pokok penduduknya. Prasyarat untuk peningkatan agroindustri adalah bahwa komponen agroindustri yang tidak dimurnikan berasal dari bahan utama di daerah maju. Wilayah Jawa Timur merupakan salah satu daerah penghasil jagung terbesar di Indonesia, sehingga memiliki potensi untuk pengembangan agroindustri berbasis jagung. Dalam industri agribisnis agraris, jaringan toko papan (SCM) diperlukan. Jaringan persediaan Papan sebenarnya adalah persiapan, rencana, dan pengendalian perkembangan data dan barang dagangan di sepanjang jaringan produksi dengan tujuan memenuhi kebutuhan klien secara efektif untuk pengelolaan sekarang dan masa depan (Rusdiana, 2014). Store network the board atau 
inventory network the executives pertama kali dikemukakan oleh Oliver dan Weber (Yuliyani, 2019). Organisasi sebenarnya dari organisasi yang terkait dengan penyediaan bahan alami, pembuatan produk, apa pun yang mengirimkannya ke klien akhir dikenal sebagai jaringan inventaris adalah teknik, perangkat, atau cara untuk menanganinya. Jaringan penyimpanan papan mulai dibuat selama tahun 1980-an dan berlanjut hingga saat ini (Bell, 2013). Di jaringan toko papan, komunikasi antara penyedia, kerangka kerja, pedagang, pengecer, dan pembeli akhir akan mempengaruhi latihan di jaringan toko. Hubungan yang baik antara rantai pasokan dalam jaringan produksi akan membawa bantuan besar bagi pembeli terakhir dan secara bersamaan akan ada manfaat tambahan bagi organisasi (Amalia \& Hairiyah, 2020). Hal ini dapat diketahui dengan memenuhi kebutuhan setiap jaringan persediaan dengan koneksi masa lalu, mulai dari penyedia bahan alami hingga pembeli konklusif. Jika dilihat dari barang dagangan yang mengalir di sepanjang jaringan persediaan dari bahan mentah hingga barang jadi, kuantitas barang dan kualitas barang merupakan hal yang harus dipenuhi. Hal ini untuk menjamin kelancaran kreasi dan selanjutnya menjamin kemajuan kolaborasi di jaringan toko. Penyedia bahan alam dapat memberikan jumlah dan sifat komponen yang tidak dimurnikan sesuai dengan permintaan produsen. Demikian pula, pembuat harus memiliki pilihan untuk memenuhi kuantitas barang untuk pembeli mereka dengan kualitas standar. (Putra, Hasiholan, \& Seputra, 2021). Menyatakan bahwa jaringan persediaan adalah suatu organisasi yang bekerja sama untuk membuat dan menyampaikan suatu barang sampai akhir. Untuk memenuhi keinginan pembeli. Salah satu cara yang dapat dimanfaatkan adalah dengan melaksanakan jaringan produksi pengurus, khususnya koordinasi dan pengendalian pergerakan setiap jenis jaringan produksi seperti yang ditunjukkan oleh (Muta'ali, Marwast, \& Christanto, 2018). Pemenuhan pelanggan dapat dilihat apakah ada koordinasi termasuk pengembangan barang dagangan, uang tunai dan data yang terintegrasi antara penghibur dalam jaringan persediaan untuk membuat barang-barang sederhana. Ditindak lanjuti sesuai jadwal dan dengan kualitas yang hebat. Koordinasi dan kerjasama dalam jaringan inventarisasi dapat dilakukan apabila terjadi hubungan yang berlarut-larut. Pemahaman yang berlarut-larut di sini tidak menggarisbawahi panjangnya hubungan yang telah terjalin, tetapi lebih menekankan keinginan untuk membangun hubungan jangka panjang antara jaringan produksi penghibur. Jaringan persediaan di Agroindustri PT. Agro Aku Bisa Jember khususnya pada perkembangan data. Dalam hal penyajian jaringan persediaan yang besar, jelas jaringan persediaan tersebut kemungkinan besar Pemenuhan keinginan pembeli dapat diakui dan akan memiliki intensitas tinggi yang dapat akhirnya membantu contoh setiap penghibur jaringan persediaan. PT. Agro Aku Bisa adalah sebuah organisasi yang bergerak di bidang perkebunan, khususnya jagung, yang terletak di Kabupaten Jember, Jawa Timur. Organisasi ini memiliki kerangka bisnis dengan bekerjasama dengan peternak daerah di sekitar Jember dengan menawarkan bundel sebagai bahan untuk perkebunan jagung termasuk benih, obat-obatan dan kompos. Oleh karena itu, sangat penting untuk memimpin evaluasi jaringan toko yang dijalankan oleh eksekutif untuk memutuskan tingkat pekerjaan saat ini dan sangat baik dapat dilihat 
pengaturan restoratif yang mungkin untuk lebih mengembangkan eksekusi jaringan toko di kemudian hari. Alasan ulasan ini adalah (1) untuk memecah pasokan PT.Agro Aku bisa (2) untuk mengetahui Bagaimana Mendistribusikan bahan baku ke petani yang bermitra di PT.Agro Aku Bisa.

Rantai pasok merupakn suatu pendekatanyang diyakini dapt untuk menyelesaikan permasalahan komoditas pertanian. Perusahaan PT.Agro Aku Bisa menerapkan supply chain dengan baik milai dari Suply bahan baku untuk didistribusikan ke petani dan hasil panen akan diproduksi untuk bahan pakan ternak

Tujuan Penelitian ini adalah untuk mengetahui kinerja manajemen rantai pasokan perusahaan PT.Agro Aku Bisa, bagaimana cara mendistribusikan bahan baku ke petani, bagaimana proses produksi dan hasil panen untuk diolah menjadi bahan pakan ternak. Dan manfat penelitian ini adalah untuk menjadikan referensi bagaimana menerapkan rantai pasokan atau supply chain dalam perusahaan agroindustri khususnya keitraan pertanian jagung.

\section{Metode Penelitian}

Penelitan dilakukan pada setiap entitias rantai pasok komoditas jangung di kabupaten Jember, Bondowoso dan situbondo. Penelitian ini tergolong pada jenis penelitian kualitiatif dengan menggunakan data primer yang meliputi wawancara dan observasi langsung. Tempat penelitian Adalah J1. Kyai Mojo I, Kaliwates, Jember,Jawa Timur. Penelitian ini di titikberatkan kepada Petani Wilayah Jember dan Sekitarnya yang bermitra dengan PT. Agro Aku Bisa, Dan Bagaimana proses Rantai Pasokannya. Periode waktu peneitian selama 4 (empat) Bulan, informan dalam penelitian ini adalah Manajer Dan Direktur produksi yang dipilih sebagai informan kunci karena memiliki informasi terkait strategi distribusi dan berbagai kebijakan Dari PT. Agro Aku Bisa Perusahaan yang bergerak di bidang pertanian khususnya Jagung Di J1. Kyai mojo I, Kaliwates, Jember. Informan penelitian bekerja sama dengan petani dengan kotrak invoice nantinya perusahaan akan mendistribusikan bahan pokok atau bahan baku ke petani seperti obat,pupuk,benih dan lain-lain, saat panen perusahaan menyalurkan hasil panen dari petani untuk diproduksikan ke perusahaan-perusahaan tertentu, informan benar-benar paham dan mengerti aktivitas produksi dan pemasaran perusahaan yang sangat diperlukan untuk mengetahui aktivita (Alizah \& Rum, 2020) Rantai pasokan supply chain perusahaan PT.Agro Aku bisa dari hulu ke hilir Strategi pengumpulan informasi Metode pengumpulan informasi dengan menggunakan prosedur pertemuan, persepsi, dan dokumentasi serta klarifikasi dari setiap strategi.

\section{Hasil dan Pembahasan}

Jaringan persediaan produk agraria agak unik dalam kaitannya dengan jaringan toko barang non-hortikultura. Hal ini karena ide bertani mudah dirusak, sistem pembentukan interaksi kumpul bergantung pada lingkungan dan musim, ada variasi dalam ukuran dan keadaan koleksi sehingga elemen-elemen ini harus dipertimbangkan dalam jaringan toko. Barang-barang agraria untuk mendapatkan kerangka jaringan toko 
yang menyeluruh, menarik, efktif dan ekonomis. Peningkatan iklim modern yang kuat pada periode global saat ini telah menjadi pemicu bagi beberapa asosiasi perusahaan untuk menyelidiki kapasitas terpendam mereka, serta mengenali elemen-elemen kunci pencapaian untuk mendominasi dalam persaingan yang semakin agresif. Inovasi yang juga berkembang pesat menjadi kekuatan untuk diterapkan di lingkungan yang serius. Upaya yang dilakukan akhirnya akan dikoordinasikan untuk memberikan barang terbaik kepada pembeli. Pengaturan item yang disajikan oleh organisasi kepada pembeli sejauh pembuatan dan tugas eksekutif adalah komitmen tenaga kerja dan item produk. Perusahaan tidak dapat bersaing dengan asumsi barang yang ditawarkan hanyalah barang dagangan, jika tidak perusahaan tidak dapat bersaing jika barang yang ditawarkan hanyalah administrasi atas keberhasilan perusahaan dalam memberikan barang terbaik kepada pembeli atau perpaduan keduanya, khususnya tenaga kerja. dan produk dalam barang-barang khusus mereka yang ideal sesuai dengan organisasi. . Memerlukan item dari perspektif yang luas adalah ujian seperti halnya peluang untuk kerangka pembuatan ikan, yang harus diselesaikan oleh organisasi. Mulai dari mengenali pelanggan hingga mencari segala kebutuhan informasi dari penyedia untuk membuat dan menyampaikan barang-barang tersebut sesuai kecenderungan pembeli yang dimunculkan. Pada dasarnya pembeli berharap mendapatkan suatu barang yang memiliki manfaat pada tingkat nilai yang memuaskan dan memadai. Untuk memiliki pilihan untuk memahami latihan pelanggan ini, setiap organisasi berusaha secara ideal untuk memanfaatkan setiap sumber daya dan kemampuannya untuk menawarkan beberapa insentif kepada asumsi pembeli. Eksekusi dan pengerahan tenaga ini tentunya memiliki konsekuensi biaya yang beragam untuk setiap organisasi, termasuk para pesaingnya. Untuk dapat menawarkan produk yang sangat menarik dengan harga yang serius, setiap perusahaan harus berusaha untuk mengurangi atau mengurangi semua biaya tanpa mengurangi kualitas produk atau prinsip yang telah ditetapkan (Aldillah, 2018). Salah satu upaya untuk menekan biaya adalah dengan mengefisienkan penyebaran materi dari penyedia. Perkembangan bahan dalam siklus apropriasi ke penyebaran barang ke tangan pelanggan. Apropriasi yang ideal untuk situasi ini adalah dicapai melalui penerapan supply chain management. Supply chain management sesungguhnya bukan merupakan suatu kondep yang baru. Menurut Turban, Raider, Porter (2004), terdapat 3 macang komponen rantain suplai, yaitu.

1. Rantai Suplai Hulu (Upstream Supply Chain) Bagian Upstream (hulu) supply chain meliputi aktivitas dari suatu perusahaan dengan para penyalurnya dan kojneksi mereka kepada pada penyalur mereka. Hubungan para penyalur dapat diperlukan kepada beberapa strata, semua jalan dari maerial. Didalam supply chain, aktivitas yang utama adalah pengadaan.

2. Manajemen rantai suplai internal (internal supply chain management) Bagian dari jaringan toko internal menggabungkan setiap siklus memasukkan barang dagangan ke pusat distribusi yang digunakan dalam mengubah kontribusi ke asosiasi dalam jaringan produksi interior, perhatian utama adalah administrasi pembuatan, pabrik, pembuatan, perakitan, dan kontrol stok . 
3. Fragmen jaringan toko hilir Jaringan toko hilir menggabungkan pergerakan dari setiap jenis yang mencakup pengangkutan barang ke klien akhir. Pada jaringan produksi hilir, penelitian ditujukan pada dispersi, pergudangan, transportasi, dan kemudian administrasi kesepakatan. Seperti yang ditunjukkan oleh jaringan persediaan Papan merupakan kemajuan lebih lanjut dari penyebaran barang para eksekutif untuk memenuhi kebutuhan pelanggan. Idenya menekankan contoh terkoordinasi termasuk proses aliran barang dari penyedia, produsen dan pengecer. Sampai pembeli. Dari sini, latihan antara penyedia dan pembeli terakhir berada dalam satu kesatuan tanpa hambatan dan hambatan yang besar, sehingga komponen data antara komponen yang berbeda terjadi dengan cara yang mudah. Jaringan inventaris para eksekutif adalah ide tentang desain pengiriman barang yang dapat menggantikan desain alokasi barang yang ideal. Contoh baru ini menyangkut latihan diseminasi, rencana pembuatan dan logistik.

a. Jaringan persediaan jagung Jaringan produksi dapat dilihat sebagai suatu kerangka kerja yang memiliki komponen-komponen yang standar, umumnya menyeluruh dan memiliki alasan tertentu. Jaringan toko barang/produk jagung memiliki komponen penghibur yang langsung berhubungan dengan tingkat jaringan toko, seperti peternak, agroindustri, pedagang dan pembeli tertentu. Selain itu, ada juga komponen penghibur yang tidak langsung terkait dengan jaringan toko, khususnya otoritas publik, lembaga keuangan atau bank dan mitra lainnya. Setiap entertainer di jaringan toko memiliki kelebihannya masingmasing yang saat ini sedang diperjuangkan. Untuk bertahan hidup dan meminimalis konflik tersebut perlunya system manajemen yang lain seperti manajemen resiko, sehingga system rantai pasok bisa terkendali dalam usaha dan untuk mencapai target dan ttujuan yang harus dicapai.

b. Identifikasi dan analisis kondisi supply chain atau rantai pasokan PT. Agro Aku Bisa Identifikasi supply chain Agroindustri PT. Agro Aku Bisa Supply chain agroindustri PT. Agro Aku Bisa terdiri Dari beberapa Pelaku Yaitu Agroindustri, Pemasok , Petani , dan Konsumen (Lihawa, Uloli, \& Rasyid, 2021).

Agroindustri Pelaku Supply chain Adalah Agroindustri. Agroindustri yang dimaksud adalah agroindustri Perusahaan Jagung. Agroindustri perusahaan Jagung yang menjadi pelaku supply chain ini berada di JL. Kyai Mojo, Kaliwates, Jember, Jawa Timur.

Pemasok Pemasok adalah pelaku Supply chain setelah Agroindustri. Pemasok yang dimaksud berasal dari beberapa perusahaan yang memproduksi pupuk, bibit tanaman, obaat-obatan untuk pertanian, Pemasok atau vendor yang bekerja sama dengan PT. Agro Aku Bisa Yakni PT. Petrosida Gresik.

Petani Petani Jagung merupakan salah satu Supply chain Yang melakukan kegiatan budidaya jagung yaitu mulai dari pembibitan sampai proses panen. Petani jagung merupakan mitra dari Agroindustri. Petani jagung yang bermitra dengan PT. Agro Aku Bisa Bersal dari Wilayah jemmber, Bondowoso, Banyuwangi dan sekitarnya 
Konsumen Pelaku Supply Chain Agroindustri Jagung Adalah Konsumen Akhir. Konsumen akhir dari Supply chain ini adalah Perusahaan perusahaan Berbagai Wilayah. Jaringan inventaris terkoordinasi. Semua organisasi membutuhkan sesuatu yang sangat konservatif untuk melakukan latihan penciptaan demi keuntungan. Untuk mewujudkan keinginan ini. Kelancaran perkembangan bahan yang dibutuhkan harus mencakup lebih dari satu jaringan produksi (Hetharia, Maarif, \& Arkeman, 2016). Variabel dasar dalam jaringan toko produktif adalah pembelian, karena tugas pembelian adalah memilih penyedia dan kemudian merakit koneksi penghubung. Tanpa penyedia yang hebat dan tanpa pembelian yang memuaskan, jaringan inventaris tidak akan berperan dalam situasi ekonomi saat ini. Jaringan produksi papan diperlukan oleh organisasi yang mengarah pada penanganan dengan kerangka kerja yang cepat, dengan alasan bahwa ide tepat waktu menonjolkan idealisme penampilan bahan dari penyedia hingga tangan tetap di tangan. udara. Ini berarti bahwa disiplin dan tanggung jawab di seluruh rantai harus benar-benar dijalankan, karena kerangka waktu yang tepat tidak menekankan organisasi atau nol saham. Sehingga dengan asumsi terjadi penyimpangan pada satu sambungan saja, maka akan mengganggu jaringan gudang bahan secara keseluruhan dan menghambat kelancaran usaha dari pihak lain, mengingat tidak adanya stok. Untuk kondisi dalam organisasi, kerangka waktu tepat waktu akan bermanfaat jika koneksi yang terhubung berada dalam satu grup. Untuk organisasi yang berfokus pada persediaan karena kualitas material atau sebagai harapan untuk mengelola iklim modern yang tidak stabil, jaringan toko para eksekutif juga diperlukan. Tugas pengurus jaringan produksi untuk organisasi semacam ini adalah mengurangi biaya persediaan, dengan alasan persediaan dalam tinjauan ini tidak ideal, akan mempengaruhi biaya penimbunan, biaya pemesanan, dan biaya backorder (apabila terjadi stock out)

\section{Kesimpulan}

Rantai pasokan agroindustri PT. Agro Aku Bisa adalah perusahaan Agroindustri - PT. Agro aku bisa - petani - Pemask - produsen - Konsumen. Dan dapat juga dikemukakan beberapa hal semakin kuat faktor Otoritas menyebabkan perasaan ketergantungan pekerjaan pada organisasi. Kekuatan organisasi mempengaruhi tanggung jawab peternak. Hal ini karena organisasi dianggap memiliki hak istimewa yang ada melalui posisi untuk mempengaruhi peternak, dan peternak berkewajiban untuk mengakui dampak ini dan menyelesaikan kewajiban mereka sesuai kesepakatan (kontrak). Tingkat kepercayaan yang rendah dan koneksi bermanfaat yang kurang positif tidak akan meyakinkan untuk mengawasi asosiasi yang lebih mudah beradaptasi daripada pengaturan formal yang mengikat secara hukum. Dalam tanggung jawab asosiasi melacak pekerjaan penting dalam kolaborasi antara organisasi dan peternak, dengan cara ini membina hubungan yang menyenangkan yang stabil Semakin layak pelaksanaan asosiasi, semakin stabil organisasi antara organisasi dan peternak. Hal ini karena asosiasi dapat memberikan insentif tambahan bagi peternak. Dengan tujuan agar organisasi berjalan dengan baik dan sempurna. 


\section{Bibliografi}

Adiputra, Rachmat. (2020). evaluasi penanganan pasca panen yang baik pada jagung (Zea mays L). Jurnal Agro Wiralodra, 3(1). https://doi.org/10.31943/agrowiralodra.v3i1.38

Aldillah, Rizma. (2018). Dinamika perubahan harga padi jagung kedelai serta implikasinya terhadap pendapatan usaha tani.

Alizah, Mozalita Nur, \& Rum, Mokh. (2020). Kinerja Pemasaran Dan Strategi Pengembangan Jagung Hibrida Unggul Madura Mh-3 Di Kabupaten Bangkalan. AGRISCIENCE, 1(2), 448-463. https://doi.org/10.21107/agriscience.v1i2.8177

Amalia, Raden Rizki, \& Hairiyah, Nina. (2020). Pemetaan Rantai Pasok Dan Analisis Nilai Tambah Komoditas Jagung Di Kabupaten Tanah Laut. Jurnal Agroindustri, 10(2), 147-155.

Bell, Gordon. (2013). Total recall. Gramedia Pustaka Utama.

Hetharia, Dorina, Maarif, M. Syamsul, \& Arkeman, Yandra. (2016). Prediksi Produksi Jagung Dalam Model Penyediaan Tepung Jagung Pada Rantai Pasok Jagung. Jurnal Teknik Industri, 6(3).

Lailia, Firda Nurul. (2014). Pengembangan kawasan agroindustri berbasis komoditas unggulan sektor pertanian kabupaten Probolinggo. Institut Teknologi Sepuluh Nopember.

Lihawa, Adriyansya, Uloli, Hendra, \& Rasyid, Abdul. (2021). Analisis Rantai Nilai (Value Chain) Pada Komoditas Jagung. Jambura Industrial Review (JIREV), 1(2), 94-103. https://doi.org/10.37905/iirev.1.2.94-103

Muta'ali, Lutfi, Marwast, Djaka, \& Christanto, Joko. (2018). Pengelolaan wilayah perbatasan NKRI. UGM PRESS.

Putra, Rahmantana Wibawa, Hasiholan, Leonardo Budi, \& Seputra, Adji. (2021). Pengaruh Bauran Pemasaran Dan Kualitas Pelayanan Terhadap Keputusan Pembelian Produk Bengkel Sinar Barito Arteri Semarang. Journal of Management, 7(1).

Rusdiana, A. (2014). Manajemen Operasi. Pustaka Setia.

Yuliyani, Yuliyani. (2019). analisis pemilihan supplier bahan baku kertas dengan metode analytical hierarchy process menuju e-supply chain management pt papertech indonesia di UNIT II. Skripsi, Universitas Muhammadiyah Magelang. 